\title{
TEACHING LANGUAGE WITH THE AID OF \\ ROTTWEILERS, SHARKS AND DNOSAURS
}

\author{
R.P. Botha \\ Department of General Linguistics \\ University of Stellenbosch
}

Bills and beasts

During 1992 and 1993, South Africans were showered with all sorts of proposals for a bill of human rights. One of these was a Charter of Fundamental Rights proposed by the governing National Party early in February 1993. As you may recall, this proposal got a mixed reception. For instance, to a commentator writing in the Washington Times [5/2/93], it was 'a document that sounds very similar to the mother of all bills of rights, the one enshrined in the U.S. constitution since the $18 \mathrm{eh}$ century'.

Other commentators, however, were less impressed with the charter of rights proposed by the National Party. Writing in the South African Sunday Times [14/12/93], Kader Asmal, for example, said about this charter:

1 This pup will turn into a Rottweiler.

And in similar vein, Firoz Cachalia and Dennis Davis commented a week later in the Sunday Times [21/2/93]: 'Kader Asmal is wrong on one point - the bill is not a rottweiler - it is a poorly drafted combination of a jurisprudential dinosaur and a political shark'. This judgement was compressed by the Sunday Times [21/3/93] into the heading:

2 No, it's not a rottweiler, but a shark and dinosaur.

Which brings me to the three general questions that I would like to address in this paper. First: What is one actually doing by calling a draft bill of human rights a Rotrweiler, a shark 
or a dinosaur? Second: What can one achieve by using language in this way? Third: Why does this use of language merit the attention of language teachers?

\section{Meaning without saying}

As for the first general question, there are various things that one is not doing by calling a draft bill a Rottweiler, dinosaur or shark. For example, it is highly unlikely that one is merely showing off one's flair for using what may be labelled 'colourful' or 'poetic language'. It is just as unlikely, at the other extreme, that one is seriously claiming that a particular bill really is a dog, a fish or a prehistoric reptile.

So what, then, is one doing by calling a draft bill of rights a Rotweiler, shark or dinosaur? In essence, one is meaning something without saying it in so many words. To see what this involves, we have to consider the meaning of the words Rotweiler, shark and dinosaur: According to a well-founded conception of meaning - which I simplify a little - the meaning of the word Rotiweiler is made up of the beliefs or ideas that people share about Rottweilers. 1

These shared beliefs include, amongst others, those listed in 3 :

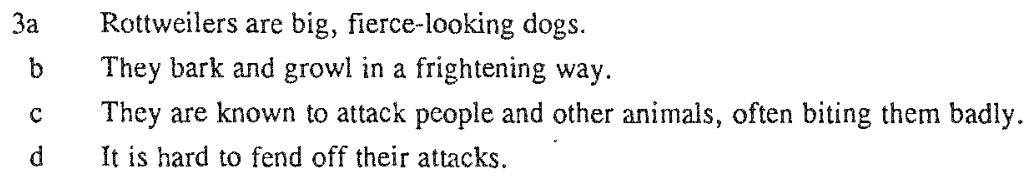

The meaning of the word shark includes, amongst others, the beliefs listed in 4 :

4a Sharks are huge fish with big jaws full of sharp teeth.

b They attack people, often maiming or killing them.

c It is very difficult to escape their attacks which normally catch people unawares.

As for the meaning of dinosaur, it includes, amongst others, the beliefs listed in 5:

5a Dinosaurs were huge, ugly creatures.

b They lived in prehistoric times.

c They were unable to adapt to changes in their environment.

d They died out long ago. 
Before proceeding, note that 3,4 and 5 are not supposed to represent factual or scientific information about Rotrweilers, sharks and dinosaurs respectively. The meaning of a word is not to be identified with factual or scientific information about the entities denoted by it. Rather, the meaning of a word represents what has been called the 'naive idea' that ordinary people share about the entities denoted by it. So, if you are the proud owner of a Rottweiler, shark or dinosaur which does not have the awesome properties listed in 3,4 and 5, there is no reason to feel deeply offended on behalf of your sweet-natured pet.

Let us return to the main point. When someone calls a bill of rights a Rotweiler, shark or dinosaur, he/she implies that the bill has certain properties, without overtly stating these properties. The beliefs making up the meaning of these words covertly suggest these properties. In the case of Rotwweiler, the beliefs $3 a-d$ suggest $6 a-d$ respectively about the National Party's charter of fundamental rights:

6 The charter looks quite dangerous.

b The language used in the charter sounds threatening.

c The charter may (eventually) turn on people, harming them gravely.

d People will find it hard to defend themselves against the charter.

Similarly, as components of the meaning of shark, the beliefs $4 a-d$ suggest $7 a-c$ respectively about the National Party's charter of rights:

7a The charter has terrifying features.

b The charter is bound to cripple or destroy (important rights of) people.

c People won't be able to escape the hurtful consequences of the charter.

Likewise, as components of the meaning of dinosaur, the beliefs 5a-d suggest 8 a-d respectively about the charter in question:

8a The charter is a highly unattractive thing.

b The charter is something from a bygone era.

c The (ideas expressed in the) charter cannot be adapted to present-day circumstances.

d The ideas expressed in the charter were abandoned long ago. 
Observe that in regard to content, 6,7 and 8 are claims or, more technically, propositions. These claims, or propositions, however, are not expressed explicitly or overtly by the utterances 1 and 2 . Hence, these claims represent covert clains or implicit propositions. ${ }^{2}$ As shown above, each of these covert claims is generated by a specific belief forming part of the meaning of Rotweiler, shark or dinosaur.

But, tuming to the second general question, what can one achieve by using utterances such as 1 and 2 that express clusters of covert claims such as 6,7 and 8 ? Various things, some at a pragmatic level and others at a rhetorical level.

\section{Highlighting and hiding}

At a pragmatic level, utterances such as 1 and 2 can be used to effect two complementary things: highlighting and hiding, ${ }^{3}$ As for highlighting: the covert claims bome by 1 and 2 focus readers' attention on what the commentators in question consider bad or dangerous properties of the National Party's charter of fundamental rights. And those properties are highlighted in a particularly effective way. A bill of rights is obviously a quite abstract kind of thing. Its abstractness makes it difficult to think and talk about. But Rottweilers, sharks and dinosaurs are quite concrete creatures to ordinary people, creatures about the characteristics of which they have definite perceptions and ideas. Thinking of a bill of rights from the perspective of such concrete creatures makes the bill and its alleged flaws much more of a real - and, thereby - dangerous object.

The utterances 1 and 2 , however, do not only highlight the allegedly bad features of the Nationalist charter of rights. At a pragmatic level, these utterances do more. By foregrounding the bad features in the way they do, 1 and 2 necessarily hide other features of this charter, some of which may be good ones. That is, in causing people to focus on certain features of the charter, these utterances keep people from focusing on other, opposing features. For example, the charter grants the rights it includes to all pcople regardless of race. Given the National Party's history of racial discrimination, the latter feature undeniably represents a good feature of the charter. But this feature is hidden by the covert claims 6,7 and 8 expressed by the utterances 1 and 2 . This bit of information cannot be conveyed by the utterances 1 or 2 , not even covertly. This is so because the meaning of Rottweiler, shark or dinosaur does not incorporate a belief that can carry the bit of positive information in question. Similarly, other good features that the charter may have are masked or hidden by the meaning of Rotrweiler, shark and dinosaur. The meaning of these words does not include the beliefs 
that can be used to covertly convey claims attributing good features to the charter. This means that the utterances 1 and 2 by implication covertly express the claim 9 as well:

9 The charter has no good features at all.

But let us move on to what one may achieve at a rhetorical level by using the utterances 1 and 2.

\section{$4 \quad$ Lulling and misleading}

In bearing covert claims such as $6,7,8$ and 9 , the utterances 1 and 2 constitute quite powerful rhetorical tools. A covert claim, we have seen, is one which is not explicitly asserted. As a consequence, covert claims are hard to spot, hard to check and hard to counter. ${ }^{4}$ Such claims often evade the kind of critical scrutiny to which overt claims are normally subjected. By using words such as Rottweiler, shark and dinosaur in utterances such as 1 and 2 , one can lull people into uncritically accepting false claims or claims which they may have questioned on critical scrutiny. Herein lies the rhetorical power of utterances expressing covert claims.

Let me illustrate this point with another example of an utterance used in the debate about the charter of rights proposed by the National Party. Kobie Coetzee, Minister of Justice at the time of this debate, responded at some length in the Sunday Times [21/2/92] to certain criticisms levelled by Kader Asmal and others at this charter. The Sunday Times [21/3/92] published Coetzee's response under the heading represented in 10 .

10

The Minister of Justice's draft bill of rights

has been likened to a Rottweiler. Now

\section{COETZEE BITES BACK}

Consider the utterance Coetzee bites back and specifically the way in which bites is used in this utterance. The meaning of bites includes the two beliefs represented in 11 .

Ila Biting (by a dog) is a form of violent action intended to injure or kill the bitten.

b Biting (by a dog) does not involve the use of reason. 
In virtue of these two components of the meaning of bites, the utterance Coetzee bites back covertly expresses the claims in 12 :

12a Coetzee reacts in a violent way in order to injure his critics.

b Coetzee's reaction does not involve the use of reason.

Since the claims $12 \mathrm{a}$ and $12 \mathrm{~b}$ are not explicitly asserted, unsuspecting readers of the Sunday Times may easily fail to identify them as claims which can be false and which ought to be subjected to critical examination. These claims, moreover, can prime people to read Coetzee's reply from a 'biting' perspective; a perspective in terms of which the reply may be expected to be devoid of any reason. From this perspective, Coetzee does not stand much more than a dog's chance of rebutting the criticisms of the National Party's charter. (Rebutting criticisms, of course, should not be confused with 'rebiting' the critics.)

\section{Teaching and tuning}

Thereby we have come to the third of the general questions: Why does the use of language for producing utterances such as 1,2 and 10 merit the attention of language teachers? The short answer is: because it has become increasingly clear that language has to be taught from a critical or an ecological perspective as well. This perspective is concerned with the immoral use of language to deceive, defraud, rob or injure pcople. Or to ridicule, degrade, oppress, disempower or dehumanize them. And utterances such as 1,2 and 10 can be used deceitfully to get people to accept claims that they would have rejected had these claims been overtly asserted.

So, what in general terms should students be taught in regard to utterances such as 1,2 and 10 ? Three things, in essence. Firstly, with the aid of striking examples - that is, Rothveiler, shark and dinosaur examples - students should be made acquainted with the distinction between overt and covert claims. And they should be shown that many seemingly innocuous utterances are dangerous in that much of their meaning or content is borne below the surface in the form of covert claims. It should, however, be made clear to students that a covert claim is not by definition false. Only careful checking can reveal whether a given covert clain is true or false. Note, incidentally, that I have not claimed above that the covert claims 6,7 and 8 are indeed false. I have claimed that, borne by the utterances 1 and 2 , these claims are covert and that, like all claims, they may be false. My analysis of the utterances 1,2 and 10, moreover, should not be misconstrued as a defence of the charter of rights in question. 
Secondly, students have to be introduced to the linguistic means or devices that can be used for expressing covert claims. In the case of 1,2 and 10 this linguistic means, of course, is metaphor: these utterances are metaphorical. 5 Students have to acquire some understanding of the general nature of metaphor, of the functions of metaphor, of the working of metaphor, and of the various types of metaphor that can be distinguished. 6

Thirdly, students have to become tuned in to the ubiquity of metaphor. There was a time when metaphor was generally believed to be 'a device of the poetic imagination and the [empty] rhetorical flourish - a matter of extraordinary rather than ordinary language'. 7 This belief, however, has given way to the view that 'metaphor is pervasive in everyday life, not just language, but in thought and action" ${ }^{8}$ An increasing number of scholars have come to believe that 'our ordinary conceptual system, in terms of which we both think and act, is fundamentally metaphorical in nature'. 9 Metaphor is currently believed by many to be a basic means of constructing and reconstructing reality. This belief prompted a famous linguist to state: 'The world is a vast elaborated METAPHOR'.10 And language is awash with metaphors: they are so numerous and commonplace that we often fail to notice them. 11

\section{Misusing versus using ineptly}

You may wonder whether students should not be urged to avoid using linguistic means which can be used for expressing covert claims. For example, shouldn't they be discouraged from using metaphorical utterances in view of the capacity that such utterances have for bearing covert claims by which fellow-speakers may be deceived? The answer has to be an emphatic 'no': metaphor is so central to language and thinking that people cannot function normally either cognitively or linguistically - without using metaphorical utterances.

Students should instead be taught the distinction between using language immorally and using language ineptly. So what does this distinction entail? Let.us pursue this question in a concrete way, enlisting once more the aid of creatures of a prehistoric sort. Suppose that you had hoped to meet at this conference Professor Steve Spielbaum, a famous Stellenbosch educationist. But to your disappointment, Professor Spielbaum failed to pitch up at any of the conference sessions. So, before leaving Stellenbosch you asked me where on campus you could find the professor. And, suppose I responded by uttering 13. 
With the aid of 13, I wished to inform you of the location of Professor Spiebaum's office: it is in an ancient building which, on account of its having so many primitive features, is called Jurassic Park by students. But in virtue of its being metaphorical, the utterance 13 can do more than to locate Professor Spielbaum's office. It can express covert claims such as $14 \mathrm{a}, \mathrm{b}$ and $c$ as well.

14 a Professor Spielbaum is academically a dinosaur.

b He has an exceedingly small brain.

c He is a member of a disappearing species.

The question is whether, by using a given utterance [i.e., 13] that generates certain covert claims [i.e., $14 a, b$ and $c$ ], I am guilty of the immoral use of language. If I did not have the intention to deceive you, the answer is 'no'. That is, if I did not deliberately use 13 to get you to uncritically accept the covert claims $14 \mathrm{a}, \mathrm{b}$ and $\mathrm{c}$ about Professor Spielbaum, 1. cannot be condemned for having abused language. Inspection may even reveal Professor Spielbaum to be a close friend of mine, a man for whose remarkable brightness I have repeatedly expressed my deepest admiration. All I intended to do by uttering 13, was to help you trace Professor Spielbaum. And when I used 13, I was not aware of the capacity of this utterance for expressing the covert claims $14 \mathrm{a}$ - c. But this does not mean that I am free of any blame. To use a strong, live metaphor without taking into account its capacity for generating covert claims that may deceive people is to use language ineptly. So my using 13 manifests linguistic ineptitude rather than language abuse.

The distinction between using language in an immoral way and using language in an inept way is crucial to critical language teaching. On the one hand, students should not be taught to act like paranoid listeners or readers, bent on finding deliberate deception underneath the surface of every second utterance. An attitude of unrestrained distrust makes normal linguistic interaction among people impossible. Such interaction requires language users to accept each other's linguistic sincerity if there is no cleas evidence pointing to the contrary. On the other hand, students should not be turned into crippled speakers and writers, fearful of using all the resources of their language, but should rather be made aware of the fact that certain linguistic means can be dangerous when used ineptly. This means that students should not be discouraged from using live metaphors and other linguistic means that have the capacity of bearing covert claims, but they should rather be taught to use language in a reflective and selfcritical way. Surely, critical language teaching that fails to cultivate in students the ability to appraise their own use of language critically is a worthless venture. 
In conclusion, I would like to sound a warning against the abuse of critical language teaching itself. It should not be misused by teachers as a means of grinding ideological axes or of propagating their own pet political views. In selecting specimen instances of language abuse for the purpose of illustrating to students how to look critically at language use, teachers should be unscrupulously impartial. Specifically, they should not concentrate exclusively on the linguistic malpractices of their ideological adversaries, excluding from critical inspection cases of language abuse by those who are spiritually their next of kin. Critical language teaching, by its very nature, cannot tolerate bias or lack of self-critical appraisal on the part of its practitioners. When it comes to the use of language for selling ideas or beliefs, saints are unicorns indeed. 


\section{NOTES}

* I would like to thank Henriëtte Murray and Theresa Biberauer for suggesting various improvements in the presentation of this paper.

1. Cf. Wierzbicka 1985:41. Strictly speaking, the meaning of a word is not made up of shared beliefs or ideas but of assumptions about shared ideas or beliefs. The meaning of Rotrweiler is made up of what people assume other people would believe and say of Rottweilers. See Wierzbicka 1985:115 for this, more sophisticated, conception of meaning.

2. Bolinger (1981:77ff.) calls such claims 'hidden propositions'.

3. For the notions of 'highlighting' and 'hiding' see Lakoff and Johnson 1980:10ff.

4. For this point see Mulholland 1994:183, Bolinger 1981:77ff.

5. Various other linguistic means of expressing covert claims are surveyed in Bolinger 1988:77ff.

6. There is a vast body of readable literature on metaphor which teachers may consult for information on these aspects of metaphor. See, for example, Leatherdale 1974, Ortony 1979, Schön 1979, Lakoff and Johnson 1980, Bolinger 1981, Johnson 1981, Soskice 1985, Cooper 1986, Kittay 1987, Lakoff and Turner 1989, Wilson 1990.

7. Cf. Lakoff and Johnson 1981:281.

8. Cf. Lakoff and Johnson 1981:281.

9. Cf. Lakoff and Johnson 1981:281.

10. Cf. Bolinger 1980:141.

11. The Appendix offers typical examples of metaphors which are according to Lakoff and Johnson (1980) and Lakoff and Turner (1989) so commonplace that people fail to notice them. 


\section{APPENDIX}

\section{Some Examples of Commonplace Metaphors}

(From Lakoff, G. and Johnson, M. Metaphors we live by. Chicago and London, University of Chicago Press, 1980.)

Argument is war: Your claims are indefensible; His criticisms were right on target; If you use that strategy, hell wipe you out; You disagree? Okay, shoot; ...

Time is money: You're wasting your time; That flat tyre cost me an hour; He's living on borrowed time; You need to budget your time; ...

Ideas are objects: I gave you that idea; 1 will have to chew on that idea; The idea is buried in terribly dense paragraphs; He trampled on the idea; ...

Linguistic expressions are containers: It is difficult to put my ideas into words; Try to pack more thought into fewer words; Your words seem hollow; ...

Communication is sending: Your reasons came through to us; Its hard to get that idea across to him; I receive you loud and clear; ...

Inflation is an entity: Inflation is backing us into a corner; We need to combat inflation; Inflation makes me sick; Inflation is taking its toll at the checkout counter and the gas pump; Inflation is breaking my back; ...

The mind is a machine: We're still trying to find out the solution to his equation; Boy, the wheels are turning now!; I am a little rusty today; My mind just isn't operating today; intellectually, we are running out of steam; ...

The mind is a brittle object: Her ego is very fragile; He broke under cross-examination; She is easily crushed; I am going to pieces; His mind snapped; ...

Visual fields are containers: The ship is coming into view; He is out of sight now; That's in the center of my field of vision; There's nothing in sight; ... 
Events are container objects: Are you in the race on Sunday; Halfway into the race, I ran out of energy; He is out of the race now; ...

Theories (and arguments) are buildings: Is that the foundation of your theory; They exploded/demolished his latest theory; The argument collapsed; The argument is shaky; We need to consiruct a strong argument for that; ...

Ideas are food: What he said left a bad taste in my mouth; All this paper has are raw facts, half-baked ideas, and warmed-over theories; I just can't swallow that claim; Let that idea jell for a while; We don't need to spoon-feed our students; ...

Ideas are people: Those ideas died off in the Middle Ages; His ideas will live on forever; He breathed new life into that idea; He is the father of modern biology; ...

Ideas are plants: That's a budding theory; She has a fertile imagination; Mathematics has many branches; That idea died on the vine; ...

Ideas are commodities: He won't buy that; That idea just won't sell; That's a worthless idea; There's always a market for good ideas; ...

Ideas are fashions: That went out of style years ago; That idea is old hat; Semiotics has become quite chic; What are the new trends in linguistics?; ...

Love is a physical force: I could feel the electricity between us; I was magnetically drawn to her; They gravitated to each other immediately; They lost their momentum; There is incredible energy in their relationship; ...

Love is war: He is known for his many rapid conquest; She fough for him, but his mistress won out; He fled from her advances; He made an ally of her mother; ...

Wealth is a hidden object: He is seeking fortune; He is a fortune-hunter; She is a golddigger; He is searching for wealth; He lost his fortune; ...

Significant is big: He is a big man in the garment industry; It was only a small crime; That was only a litle white lie; His accomplishments tower over those of lesser men; I was astounded by die enomiry of the crime; ... 
Seeing is touching; eyes are limbs: I can't take my eyes off her; He sits with his eyes glued to the TV; She ran her eyes over everything in the room; He wants everything within recich of his eyes; Their eyes met; ...

The eyes are containers for the emotions: I could see the fear in his eyes; His eyes were filled with anger; There was passion in her eyes; Her eyes welled with emotion; Love showed in his eyes; ...

Emotional effect is physical contact: His mother's death hit him hord; That idea bowled me over; She's a knockout; That blew me away; ...

Physical and emotional states are entities within a person: He has a pain in his shoulder; Don't give me the flu; His pain wen away; His depression returned; He could barely contain his joy; I have got to shake off this depression - it keeps harping on; Wipe that sneer off your face, private!; ...

Vitality is a substance: She is brimming with vim and vigor; She is oveflowing with vitality; I'm drained; That took a lot out of me; He's devoid of energy; ...

Life is a container: Life is empry for him; Her life is crammed with activities; His life contained a great deal of sorrow; Live your life to the fullest; ...

Life is a gambling game: I'll take my chances; The odds are against me; I've got an ace up my sleeve; It's a toss-up; He's bluffing; Those are high stakes; ...

Happy is up; sad is down: I am feeling up; That boosted ny spirits; My spirits rose; I'm feeling down; I'm depressed; My spirits sank; ...

Conscious is up; unconscious is down: Get up; Wake up; I'm up already; He fell asleep; He dropped off to sleep; He sank into a coma; ...

Health and life are up; sickness and death are down: He's at the peak of his health; Lazarus rose from the dead; He's sinking fast; He fell ill; ...

More is up; less is down: My income rose last year; The number of books printed each year keeps going up; His income fell last year; If you're too hot, turn the heat down; He is underage; ... 
High status is up; low status is down: He has a lofty position; She'll rise to the top; He has little upward mobility; He's at the bottom of the social hierarchy; She fell in status; He's climbing the ladder; ...

Good is up; bad is down: Things are looking up; We hit a peak last year; but it's been downhill ever since; Things are at an all-time low; ...

Virtue is up; depravity is down: He is high-minded; She is upright; That was a low trick; I won't stoop to that; Don't be underhanded; ...

Rational is up; emotional is down: The discussion fell to the emotional level, but I raised it back up to the rational plane; We put our feelings aside and had a high-level intellectual discussion of the matter; He couldn't rise above his emotions; ... 


\section{REFERENCES}

Bolinger, L. 1981. Language - The Loaded Weapon. The Use and Abuse of Language Todary. London and New York: Longman.

Cooper, D.A. 1986. Melaphor. Oxford: Basil Blackwell.

Johnson, M. 1981. Introduction: metaphor in the philosophical tradition. In Johnson (ed.) $1981: 3-47$.

Johnson, M. (ed.) 1981. Philosophical Perspective on Metaphor. Minneapolis: University of Minnesota Press.

Kittay, E.F. 1987. Metaphor. Its Cognitive Force and Linguistic Structure. Oxford: Clarendon Press.

Lakoff, G. and Johnson, M. 1980. Metaphors We Live By. Chicago and London: University of Chicago Press.

Lakoff, G. and Turner, M. 1989. More Than Cool Reason. A Field Guide to Poetic Metaphor. Chicago and London: University of Chicago Press.

Leatherdale, W.H. 1974. The Role of Analogy, Model and Metaphor in Science. Amsterdam: North Holland Publishing Company.

Muholland, J. 1994. Handbook of Persuasive Tactics. A Practical Guide to Language. London and New York: Routledge.

Ortony, A. 1979. Metaphor: a multidimensional problem. In Ortony (ed.) 1979:1-16.

Ortony, A. (ed.) 1979. Metaphor and Thought. Cambridge etc.: Cambridge University Press.

Schön, D.A. 1979. Generative metaphor: a perspective on problem-setting in social theory. In Ortony (ed.) 1979:254-283.

Soskice, J.M. 1985. Metaphor in Religious Language. Oxford: Clarendon Press. 
Wilson, J. 1990. Politically Speaking. The Pragmatic Analysis of Political Language. Oxford: Basil Blackwell.

Wierzbicka, A. 1985. Lexicography and Conceprual Analysis. Ann Arbor: Karoma. 